\title{
A social work study on different entrepreneurship opportunities
}

\author{
Zahra Zakeri Nasrabadi $^{\mathbf{a}^{*}}$, Asghar Nikbakht ${ }^{\mathrm{b}}$ and Ali Solimani Rad ${ }^{\mathrm{b}}$
}

${ }^{a}$ Department of Social science, Payam Noor University, PoBox19395-3697, Tehran, I.R .of IRAN

${ }^{b}$ Department of Economic ,khomeinishar Branch, Islamic Azad University ,Isfahan ,Iran

\begin{tabular}{l}
\hline A R T I C L E I N F O \\
\hline Article history: \\
Received March 15, 2012 \\
Received in Revised form \\
March, 15, 2012 \\
Accepted 16 May 2012 \\
Available online \\
May 19 2012 \\
\hline Keywords: \\
Entrepreneurship \\
Job opportunity \\
Women \\
Entrepreneurs
\end{tabular}

A B S T R A C T

\begin{abstract}
Entrepreneurs are big potentials for developing economy in any countries. They provide new job opportunities and help economy boost. There are literally many industries, which rely on new these people and they are considered as the primary source of generating new jobs. In this paper, we discuss three entrepreneurship opportunities including universities, technical and vocational centers and women. Universities are able to educate highly skilled people and send them to business and they are able to create new ideas. Technical and vocational centers are, in fact, the best place for training basic or recent advances in technological skills through short term or long term planning. The survey also indicates that women can be considered as a good source of job creation. In this paper, we review the recent related literature on entrepreneurship opportunities in the world and discuss some of the related issues more specifically in Iran.
\end{abstract}

\section{Introduction}

During the past few years, there have been various global turbulences and many people have lost their jobs. Many countries have gone under server cost reduction by eliminating several public jobs. In such circumstances, entrepreneurship is considered as a remedy for unemployment and growth issues (Ibrahim \& Galt, 2011). However, to improve entrepreneurship and to create entrepreneurs who can create new jobs, sufficient human resources and knowledge base are strongly required on national level. Entrepreneurship education receives more attention for constructing entrepreneurship driven economy by making individuals gaining entrepreneurial skills, knowledge and mindsets. As a substantial segment of the formal education on creating entrepreneurs, entrepreneurship courses in higher education must be considered more carefully.

In this paper, we present some insights about the relative importance of three units including technical and vocational centers, universities as well as women to promote entrepreneurship opportunities in the world. The focus of this paper is to explore these opportunities in Iran and provide some suggestions to improve entrepreneurship opportunities.

* Corresponding author. Tel.: 989103008682

E-mail addresses: zakeri@hr.isfpnu.ac.ir (Z. Zakeri Nasrabadi) 


\section{Literature survey}

Askun and Yıldırım (2011) investigated entrepreneurship education in public universities in Turkey by analyzing Web sites of 360 academic units including business administration and engineering faculties, science and technology, social sciences institutes of 95 public universities in Turkey. They reported that entrepreneurship courses in public universities in Turkey had not have good materials to provide necessary skills required for creating entrepreneurs who could contribute to economic growth and employment for students.

Berglann et al. (2011) performed a comprehensive survey on the origins and outcome of entrepreneurship on the basis of exceptionally comprehensive Norwegian matched worker-firmowner data. They defined entrepreneurship in terms of not only self-employment, but also employment in partly self-owned limited liability firms. Based on this extended entrepreneurship concept, they reported that entrepreneurship could be profitable and it could raise income variability. The primary keys of the decision to become an entrepreneur are occupational qualifications, family resources, gender, and work environments.

Zhang et al. (2009) performed a survey on gender differences in the genetic impacts on the tendency of people to act as entrepreneurs. They investigated two mediating variables through which genetic items could influence this tendency including extraversion and neuroticism. They reported that females had a strong genetic impact and zero shared-environmental impacts on their tendency to act as entrepreneurs. On the contrary to what many think, males demonstrated zero genetic impact, but a large shared-environmental impact. They discussed this sharp change in genetic impacts on entrepreneurship across gender groups and highlight the various challenges that men and women encountered in their entrepreneurial endeavors.

One primary question in this survey is whether anyone can become entrepreneur or not. Panc et al. (2012) studied some psychological characteristics, which differentiate the students who became entrepreneurs from the aspiring ones. They compared those who had just participated in a training for developing entrepreneurial skills (123) with those who started entrepreneurial activity after the training (40) and reported that entrepreneurs' scores were higher on the openness factor, which means they were more optimistic and enthusiastic. However, they did not find any significant differences on the extraversion, consciousness and agreeableness factors.

Ekinsmyth (2011) examined practices of an illustrative sample of UK mumpreneurs, a sub-group of female entrepreneurs who operated at the interface between paid work and motherhood, who were increasing numerically, and who were carving for themselves, a sub-culture of entrepreneurship. They played policy-importance, not least because the UK government had recognized mothers as a group who needed to be encouraged into business ownership. She reported that policy makers needed to realize better some key aspects of this entrepreneurial activity before their interventions could be efficient.

Aidis et al. (2008) performed a comparative perspective to study the ways in which institutions and networks had impacted entrepreneurial development in Russia. They reported that Russia's institutional environment was important in describing its relatively low levels of entrepreneurship development, where the latter was measured in terms of both number of start-ups and of existing business owners. Besides, Russia's business environment and its consequences for the role of business networks contributed to the advantage of entrepreneurial insiders to entrepreneurial outsiders in terms of new business start-ups.

Non Government Organizations (NGOs), which demonstrate its presence as a third sector apart from public sector and private sector nowadays, carry a supporting mission where many public and private sectors cannot accomplish such mission. Soysekerci and Erturgut (2010) investigated the position of NGOs whose activities became substantially distinctive throughout the world. The environment 
framing the focus interest of investigation is built by the improvement of NGO's entrepreneurship at Vocational Schools in Turkey. It looks rational to collect the social entrepreneurships of pre-bachelor students such as project development, developing project idea, application, creating design units under the department like NGO. They claimed that NGOs, which have a wide area of student employability after graduation, have a great importance for generating a popular attraction.

One important question in our mind is to know the effect of short course training programs or NGO training services. Allais (2012) investigated some experiences with 'skills development' in South Africa to contribute to broader debates about 'skills' and the relations between vocational education and development. There are many policy interventions and the creation of new educational systems for skills development in South Africa but it seems that many of them are widely failed to lead to an increase in numbers of skilled workers.

Allais (2012) studied some of the underlying issues for this by considering South African policies and educational systems and compared their results with developed countries. They reported that in South African media a skills shortage, coupled with an inflexible labor market, were the leading causes of unemployment. The South African experience explained how difficult it was to develop robust and coherent skills development in the context of inadequate social security, high levels of job insecurity, and high levels of inequalities.

For over three decades, Palestinian residences who lived in Gaza strip were accounted as the most unemployed people in the world. Hilal (2012) studied the possibilities and limitations of endeavor to improve economic and human development of marginalized groups Women and Youth, within the overall political and economic context of the occupied Palestinian territories. The issue was performed through the particular cases of two successful frameworks of vocational education and training (VET) provided by NGOs. Hilal (2012) investigated the challenges associated with the overall economic and political context, and its limitations at overcoming marginalization, reducing poverty and enhancing wellbeing. Hilal (2012) demonstrated the impact of the human development method on expanding the impacts of VET within such context, increasing labor force participation rates, employment and income creation of youth and women.

Goby and Erogul (2011) explained that the United Arab Emirates (UAE) sets new standards of support for women in business ventures as it tries to help all its citizens in the economic and social development of this rapidly changing country. They presented a survey to review four key areas influencing the success of UAE female entrepreneurship. The first one was associated with the legislative changes to enhance female entrepreneurial achievement. The second one was related to the socio-cultural realities constraining women in business ventures. The third factor was the impact of the UAE's strongly collectivist culture on business networking among women. Finally, UAE women's motivation for entrepreneurial is the last option, which gives more options for more secure employment.

Mouzakitis (2010) performed another investigation on the role of VET curricula in economic development. He explained that globalization is one of the important issues of discussion since it has a precise influence on every body's life. Therefore, he discusses that to compete on the global stage and meet the globalization challenges successfully we have to make substantial improvements in terms of improving the effectiveness of the VET instruction based on specific design of curricula. These days, knowledge and technologies are renewed at a tremendous increasing trend and to meet the resulting updated requirements of economic changes, our educational planning has to be shifted to fit its contents with new knowledge. Globalization and the new emerging economic and social order demand new policies and strategies to educational processes. 
2234

Mouzakitis (2010) explained the findings of such a research conducted to specify the necessary requirements, which need to be satisfied through the implementation of VET programs considered to be the most effective tools of meeting globalization demands. von Graevenitz et al. (2010) presented a framework for learning in which entrepreneurship education created signals to students. Their model was tested using some information from a obligatory entrepreneurship course. Using ex-ante and ex-post-survey responses from students, they found out that intentions to found decline somewhat although the course had significant positive impacts on students' self-assessed entrepreneurial skills. The empirical survey supported the hypothesis that students receive informative signals and learn about their entrepreneurial aptitude.

Nearly half of the world's populations are women and they could be the primary source of generating wealth and revenue. These days, married couple often work together to cover their life's expenses. Heilman and Chen (2003) investigated the experiences that women and minorities met in organizational settings that result in frustration and discontent with corporate life and their opportunities for advancement. They recommended that such experiences could push many of these individuals out of work, absorbing them to entrepreneurship as an alternate route to both personal and professional success. They discussed different issues, which has appeared to these experiences and a consideration of how entrepreneurship appeared to provide a solution to them. It also disclosed some of the potential pitfalls of entrepreneurship for women and minorities. However, they urged organizations to recognize the unique problems women and minorities face and the necessity of addressing these problems if they wish to keep these potentially valuable members of the workforce.

Godwyn (2009) explained that in spite of serving women who are socially and economically disadvantaged, and chronically under-funded and short-staffed, Women's Business Centers (WBCs) in the United States had been successful in helping women start businesses (Langowitz et al., 2006). Godwyn (2009) determined the social mechanisms, which explain the success of WBCs by investigating some theories. Godwyn (2009) reported that techniques implemented by WBCs to engender intra-group solidarity and neutralize the stereotype threat experienced by many female entrepreneurs could be applied to a variety of educational and workplace environments to create "identity safety".

\section{Guidelines for entrepreneurship opportunities in Iran}

In this section, we provide some guidelines on how we can improve the role of universities for adding more on economy. There are many universities around the world to create entrepreneurship opportunities. MIT is a clear example of such cases where during the years of $90^{\text {th }}$ there were about 150 firms generated from this school generating well above 230 billion dollars annually. Of course MIT is an exceptional case but it is possible to build a good framework in other universities located in countries like Iran. There may be some barriers but the author believes that it is possible to increase students' awareness about creating wealth from science and building small and medium business units inside the universities.

Technical and vocational centers are, in fact, the best place for training basic or recent advances in technological skills through short term or long term planning. However, we need to increase students' awareness on how these short-term programs are designed to help them start their own new ideas. The relative importance of these programs is that they could build a bridge between the entrepreneurs and business environment. We need to teach people on how to increase their skills on catching the new opportunities on the market and build their own business units.

Through the literature review of this paper, we have explained that women could significantly contribute to world's economy and in Iran. There is no doubt that when these people are highly educated it will become possible to share their thoughts in economy. Nevertheless, there are many cases where many cultural, economical and social barriers do not let them explore their expertise. 


\section{Conclusion}

In this paper, we have reviewed the recent literature on the role of different items on entrepreneurship opportunities in the world. We have explained that universities could build good framework for establishing new entrepreneurship opportunities. One obvious but exceptional example is the emerge of many web based enterprises such as Google, Facebook, Yahoo, etc. The other entrepreneurship opportunities come from technical and vocational centers where people can learn several skills by taking part in short term training courses. These programs help people become familiar with recent advances on technology and use them within small and medium enterprises. Finally, the last entrepreneurship opportunities are associated with women who are accounted for half of the population of the world.

\section{Acknowledgment}

The authors would like to thank the officials of Islamic Azad University for their support on executing this survey research.

\section{References}

Aidis, R., Estrin, S., \& Mickiewicz, T. (2008). Institutions and entrepreneurship development in Russia: A comparative perspective. Journal of Business Venturing, 23(6), 656-672

Allais, S. (2012). Will skills save us? Rethinking the relationships between vocational education, skills development policies, and social policy in South Africa. International Journal of Educational Development, 32(5), 632-642

Askun, B., \& Yıldırım, N. (2011). Insights On Entrepreneurship Education In Public Universities In Turkey: Creating Entrepreneurs Or Not? Procedia - Social and Behavioral Sciences, 24, 663-676.

Berglann, H., Moen, E.R., Røed, K., Skogstrøm, J.F. (2011). Entrepreneurship: Origins and returns. Labour Economics, 18(2), 180-193.

Ekinsmyth, C. (2011). Challenging the boundaries of entrepreneurship: The spatialities and practices of UK 'Mumpreneurs'. Geoforum, 42(1), 104-114.

Goby, V.P., \& Erogul, M. S. (2011). Female entrepreneurship in the United Arab Emirates: Legislative encouragements and cultural constraints. Women's Studies International Forum, 34(4), 329-334

Godwyn, M. (2009). “This Place Makes me Proud to be a Woman”: Theoretical explanations for success in entrepreneurship education for low-income women. Research in Social Stratification and Mobility, 27(1), 50-64.

Heilman, M.E., Chen, J.J. (2003). Entrepreneurship as a solution: the allure of self-employment for women and minorities. Human Resource Management Review, 13(2), 347-364.

Hilal, R. (2012). Vocational education and training for women and youth in Palestine: Poverty reduction and gender equality under occupation. International Journal of Educational Development, 32(5), 686-695.

Ibrahim, G., \& Galt, V. (2011). Explaining ethnic entrepreneurship: An evolutionary economics approach. International Business Review, 20(6), 607-613.

Langowitz, N., Sharpe, N., \& Godwyn, M. (2006). Women's Business Centers in the United States: Effective entrepreneurship training and policy implementation. Journal of Small Business and Entrepreneurship, 19(2).

Mouzakitis, G.S. (2010). The role of vocational education and training curricula in economic development. Procedia - Social and Behavioral Sciences, 2(2), 3914-3920.

Panc, I., Mihalcea, A., \& Panc, T. (2012). Entrepreneurship as a career choice for Romanian undergraduate students: who takes it from intention to action. Procedia - Social and Behavioral Sciences, 33, 712-716. 
Soysekerci, S., \& Erturgut, R. (2010). Improvement of non-governmental organization entrepreneurship in vocational schools: Turkey case. Procedia - Social and Behavioral Sciences, 2(2), 1849-1854.

von Graevenitz, G., Harhoff, D., \& Weber, R. (2010). The effects of entrepreneurship education. Journal of Economic Behavior \& Organization, 76(1), 90-112

Zhang, Z., Zyphur, M.J., Narayanan, J., Arvey, R.D., Chaturvedi, S., Avolio, B.J., Lichtenstein, P., \& Larsson, G. (2009).The genetic basis of entrepreneurship: Effects of gender and personality. Organizational Behavior and Human Decision Processes, 110(2), 93-107 